\title{
Conferência Mundial sobre Determinantes Sociais da Saúde
}

A Conferência Mundial sobre Determinantes Sociais da Saúde (CMDSS) realizada no Rio de Janeiro, de 19 a 21 de outubro de 2011, representou um importante avanço no atual movimento global sobre os DSS iniciado em 2005 com a criação da Comissão sobre DSS (CSDH) da OMS. Essa Comissão, durante seu mandato encerrado em 2008 com a entrega do relatório final, desempenhou um extraordinário papel de promoção do tema dos DSS na agenda global, mobilizando governos, especialistas e organizações da sociedade civil.

O relatório da CSDH recomendava que para uma ação sustentável sobre os determinantes seria necessária a criação de uma ampla parceria entre diversos atores como pesquisadores, tomadores de decisão, gestores, ativistas e outros. A CMDSS deu sem dúvida uma importante contribuição para a criação dessa rede de colaboração. O próprio slogan da Conferência, Todos pela Equidade, claramente expressa a concepção de que a construção da equidade em saúde exige a contribuição de todos os setores do governo, de todos os segmentos da sociedade e da comunidade internacional em ações organizadas por políticas públicas baseadas em evidências que incidam sobre os determinantes sociais da saúde.

A CMDSS constituiu-se num importante espaço de intercambio para discussão de experiências e de conhecimento científico acumulado, permitindo avançar na definição de estratégias e metodologias de ação sobre os DSS, bem como catalisar uma ação global coordenada para combate às iniquidades em saúde.

Participaram da CMDSS delegações oficiais de 120 países, especialistas e representantes de organizações da sociedade civil de todo o mundo, num total de mais de 1.200 pessoas. Esses números são uma clara manifestação de que os DSS ocupam um lugar de destaque na agenda global de saúde. A Declaração do Rio (http://cmdss2011.org/site/wp-content/ uploads/2011/10/Rio-Political-Declaration-on-SDH-20111021.pdf), além de expressar o compromisso político dos governos dos países presentes, coloca claras definições estratégicas que são aprofundadas no documento técnico da CMDSS (http://cmdss2011.org/site/ wp-content/uploads/2011/10/Documento-Tecnico-da-Conferencia-versão-final.pdf). Esses dois documentos oferecem aos governos dos países e demais atores interessados uma valiosa orientação para a definição de políticas, planos e programas de ação sobre os DSS.

O Brasil contribuiu de maneira destacada para o sucesso da CMDSS, tanto em sua organização e financiamento como em contribuições substantivas para as discussões técnicas. A expectativa agora é aproveitar o momento proporcionado pela conferência para o fortalecimento e implantação de políticas públicas que tenham o combate às iniquidades de saúde como preocupação central. Para que isso ocorra é necessário o aprofundamento de um amplo debate de temas relacionados aos DSS, tanto em setores de governo como da academia e da sociedade civil. A ENSP/Fiocruz, por intermédio de seu Centro de Estudos, Políticas e Informação sobre DSS, deverá desenvolver uma série de atividades nesse sentido, tais como a manutenção do Portal http:/ /www.cmdss2011.org e o lançamento do Observatório sobre Iniquidades em Saúde, para seguimento de tendências das iniquidades e análise de impacto de políticas. CSP devem contribuir com esse processo, promovendo e divulgando a produção científica brasileira que sirva de apoio ao uso de recursos públicos em políticas e programas de comprovada efetividade.

Alberto Pellegrini Filho

Coordenador do Centro de Estudos, Políticas e Informação sobre

Determinantes Sociais da Saúde, Escola Nacional de Saúde Pública Sergio

Arouca, Fundação Oswaldo Cruz, Rio de Janeiro, Brasil.

pellegrini@fiocruz.br 


\section{The World Conference on Social Determinants of Health}

The World Conference on Social Determinants of Health (WCSDH), held in Rio de Janeiro on October 19-21, 2011, was an important stride in the current global movement on SDH launched in 2005 with the creation of the WHO Commission on SDH (CSDH). During its term, which concluded in 2008 with the submission of the Final Report, the Commission played an extraordinary role in promoting the theme of SDH on the global agenda, mobilizing governments, experts, and civil society organizations.

The CSDH report highlighted that sustainable action on the determinants would require the creation of a broad partnership between several actors such as researchers, policymakers, policy implementers, activists and others. The WCSDH certainly made an important contribution to the creation of this collaborative network. The slogan of the Conference itself, "All for Equity", clearly expresses the concept that achieving equity in health requires the contribution of all sectors of government, all segments of society, and the international community in organized action for evidence-based public policies that impact the social determinants of health.

The WCSDH served as an important forum for exchange and discussion of experiences and accumulated scientific knowledge, fostering progress in the definition of action strategies and methodologies on SDH, as well as catalyzing coordinated global action to fight health iniquities.

Participation in the WCSDH included official delegations from 120 countries, experts, and representatives of civil society organizations from around the world, with a total of 1,200 participants. These figures are a clear manifestation that SDH occupy an outstanding place on the global health agenda. The Rio Declaration (http://cmdss2011.org/site/ wp-content/uploads/2011/10/Rio-Political-Declaration-on-SDH-20111021.pdf), besides expressing the political commitment of the participating countries, makes clear strategic definitions that are detailed in greater depth in the WCSDH Technical Document (http:// cmdss2011.org/site/wp-content/uploads/2011/10/Documento-Tecnico-da-Conferenciaversão-final.pdf). These two documents provide the countries' governments and other stakeholders with valuable orientation for the definition of policies, action plans, and programs on SDH.

Brazil made an outstanding contribution to the success of the WCSDH, both in its organization and financing, as well as through substantive contributions to the technical discussions. The expectation now is to take advantage of the Conference momentum to strengthen and implement public policies whose central concern is to combat health iniquities. This will require an in-depth and comprehensive debate on themes related to SDH in government, academia, and civil society. The Brazilian National School of Public Health at the Oswaldo Cruz Foundation (ENSP/Fiocruz), through its Center for Studies, Policies, and Information on SDH, plans to develop a series of activities in this direction, such as maintaining the Portal http://www.cmdss2011.org and launching the Observatory on Health Iniquities for follow-up and analysis of policy impact. Cadernos de Saúde Públical Reports in Public Health should contribute to this process, promoting and publicizing the Brazilian scientific production that can provide input for the use of public funds in policies and programs with proven effectiveness.

Alberto Pellegrini Filho

Coordenador do Centro de Estudos, Políticas e Informação sobre

Determinantes Sociais da Saúde, Escola Nacional de Saúde Pública Sergio

Arouca, Fundação Oswaldo Cruz, Rio de Janeiro, Brasil.

pellegrini@fiocruz.br 